\title{
The land tenure and the land use among supiori in Papua
}

\section{Penguasaan dan pemanfaatan tanah adat orang Supiori, Papua}

\author{
Simon Abdi K. Frank ${ }^{1}$, Agustinus Wenehen1, Usman Idris ${ }^{1}$ \\ ${ }^{1}$ Department of Anthropology, Cenderawasih University, Indonesia. \\ E-mail correspondence: simmon frank@yahoo.com
}

\begin{tabular}{|c|c|}
\hline ARTICLE INFO & ABSTRACT \\
\hline $\begin{array}{l}\text { Keywords: } \\
\text { Adat; Papua; land tenure; } \\
\text { Ethnography; customary } \\
\text { land; Supiori People. } \\
\text { How to cite: } \\
\text { Frank, S.A.K., Wehene, } \\
\text { A., Idris, U. (2020). } \\
\text { penguasaan dan } \\
\text { pemanfaatan tanah adat } \\
\text { orang Supiori, Papua. } \\
\text { ETNOSIA: Jurnal } \\
\text { Etnografi Indonesia. 5(1): } \\
\text { 105 - 118. } \\
\\
\text { DOI: } \\
\text { 10.31947/etnosia.v5i1.9924 }\end{array}$ & $\begin{array}{l}\text { This article aims to explore various forms of land tenure and land use } \\
\text { in Sorendiweri Village in East Supiori District, Papua Province. This } \\
\text { research uses descriptive research using ethnography. The technique } \\
\text { of determining informants is done purposively by determining key } \\
\text { informants first that guides researchers to search for further } \\
\text { informants. Data collection techniques used are in-depth interviews } \\
\text { and FGD (Focus Group Discussion). Data analysis was carried out } \\
\text { based on the factual culture of the community. The results show that } \\
\text { the pattern of land tenure in the local population is communal at the } \\
\text { clan level. Then, according to the local population, psychomo-logical } \\
\text { and historicize view of customary land is very dominant because it } \\
\text { states that customary land tenure in popular clans such as Sauyas that } \\
\text { is more in line with history and relationships between clans. In } \\
\text { addition, land tenure conflicts often occur because of the spread of land } \\
\text { clearing in customary rights for infrastructure development and etc. }\end{array}$ \\
\hline
\end{tabular}

\section{Pendahuluan}

Riset mengenai tanah adat sudah banyak dilakukan diberbagai wilayah Indonesia, tak terkecuali Papua. Studi-studi tersebut, selain telah memotret sejumlah konflik kepentingan atas hak pengelolaan dan penguasaan tanah antara pihak luar (pemerintah/swasta) dengan masyarakat setempat. Tetapi juga telah merekomendasi sejumlah alternatif penyelesaian, baik melalui perbaikan kebijakan dan regulasi, sampai merancang model penanganan dan pendampingan hukum kepada masyarakat setempat dalam menuntut haknya (Amahorseya, 2008; Bahriadi \& Lucas, 2002; Husen, 2002; Ngo, 1992; Ruwiastuti, 1997; Soemardjono, 2001; Suheri, 2015; Zakaria, 2000). Lalu pertanyaannya adalah mengapa masih terjadi konflik dan bagaimana strategi penyelesaiannya? Aktor, institusi dan instrumen apa saja yang dibutuhkan? Inilah sejumlah isu, ketika meneropong konflik tanah di Indonesia dari kawasan perbatasan Papua yang sampai saat ini masih terus berlangsung dan seakan-akan tak pernah 
selesai, meskipun telah ada upaya hukum maupun pembayaran ganti rugi. Kondisi ini mengimplikasikan bahwa pendekatan penanganan konflik tanah selama ini, tidak sepenuhnya terakomodasi atau diterima oleh masyarakat adat. Ada perbedaan perspektif antara pihak luar dan masyarakat adat dalam proses pengalihan hak yang hendak digunakan bagi kepentingan pembangunan. Dampaknya adalah masyarakat adat mulai termarginal dan tersisih, akibat kalah dan lemah. Mereka juga merasa diperlakukan tidak adil, termasuk hak-hak dasar atas tanah berserta seluruh eksistensinya. Akibatnya selalu muncul upaya konfrontasi melalui tindakan anarkis dan kekerasan, sebagai upaya perlawanan.

Sebuah studi Patriadi memperlihatkan bahwa fenomena ini menempatkan masyarakat adat dalam situasi sulit (Patriadi, 2010). Secara de facto mereka bagian dari satu entitas politik yang namanya negara (nation-state), namun mereka hampir tak pernah merasakan kehadiran negara, terutama dalam penanganan masalah sosial-ekonomi. Mereka seakan dipaksa memiliki nasionalisme tanpa menikmati hak-hak dasar sebagai anggota suatu nation. Kondisi yang demikian rawan bagi kedaulatan negara kita terhadap wilayah perbatasan, karena wilayah perbatasan bukanlah sekedar dalam artian fisik (borderline) tapi juga menyangkut penduduk dan identifikasi politik. Jika making of nation merupakan fungsi dari pembangunan sosial, ekonomi dan politik, maka minimnya kehadiran negara sangat mungkin akan mempengaruhi identifikasi politik mereka akibat tererosinya imagined state dalam memori mereka. Dengan begitu, fokus riset ini tidak lagi memperhadapkan pertentangan kepentingan antara kedua pihak, seperti periset-periset sebelumnya, akan tetapi mulai menyelam dan mendeteksi terlebih dulu kondisi sistem penguasaan dan pemanfaatan tanah masyarakat. Lalu digunakan sebagai acuan untuk melakukan penataan dan penanganan konflik tanah yang digerakkan sendiri oleh masyarakat, melalui institusi dan pranata lokal mereka. Pendekatan ini, diharapkan selain secara efektif akan membangkitkan kesadaran dan partisipasi mereka diberbagai program pembangunan, tapi juga untuk meningkatkan daya resistensi dan memproteksi hak-hak dasar dari berbagai intervensi luar.

Konsistensi masyarakat dalam mempertahankan hak tanah adatnya walaupun masih bersifat tradisi lisan, harus dipahami sebagai suatu keputusan logis. Studi Wenehen, pada Suku Bangsa Walsa dan Fermanggem yang berdiam di tapal batas antara Papua dan Papua Nugini di Distrik Waris Kabupaten Keerom, memperlihatkan bahwa klaim pemilikan atas tanah adat bukan saja dilihat pada tataran fisik atau tempat masyarakat mencari makan, akan tetapi juga berkaitan dengan sejarah lokal, struktur sosial, institusi dan pranata sosial budaya, sebagai bentuk aktualisasi dari rational and analitical basic dalam menginterpretasi tanah sebagai seorang ibu atau rahim mama (Petzkha Vai) yang berkorelasi dengan semua arena kehidupan mereka (Wenehen, 1999). Klaim kepemilikan ini terpecah-pecah dalam unit-unit sosial tingkat suku, keret dan marga berdasarkan perang suku, migrasi awal moyang, perkawinan, anak angkat, hadiah, bayar kepala dan bayar jasa. Studi ini menyimpulkan bahwa konflik tanah yang terjadi, bukan saja akibat intervensi kepentingan luar dalam mengeksploitasi sumber daya alam di kawasan tersebut, akan tetapi konflik internal antar unit-unit sosial lebih dominan dan sifatnya bersirkulasi. Artinya, konflik tersebut bisa saja berawal dari dalam unitunit sosial, kemudian merembes dengan pihak luar, maupun sebaliknya. 
Guna semakin memperluas wilayah riset yang telah dilakukan periset sebelumnya, maka tujuan riset ini akan menyelam dan memotret akar-akar persoalan tanah adat pada penduduk di Kampung Sorendiweri Distrik Supiori Utara Kabupaten Supiori. Melalui riset ini diharapkan akan merancang model penataan tanah adat yang berbasis institusi lokal untuk resolusi konflik dan pemberdayaan masyarakat. Tujuannya untuk mempersiapkan masyarakat adat secara dini, sebelum mereka menghadapi proses perubahan yang lebih dahsyat di masa mendatang yang mungkin semakin kompleks, terutama setelah wilayah ini berkembang lebih maju. Percepatan pembangunan yang bertumpu pada peningkatan dan perbaikan struktur ekonomi diperlukan berbagai sumber daya pendukung. Tanah sebagai salah satu sumber daya tersebut, hingga kini belum maksimal memberikan kontribusi, karena masih terus diwarnai konflik kepentingan (vertikal dan horizontal) yang sulit dicari penyelesainnya.

Umumnya problematika persoalan tanah yang mencuat saat ini, nyaris selalu didekati dengan dimensi manejemen dan teknologi pertanahan. Keduanya merupakan model pendekatan penataan tanah yang menjadi idola bagi para perencana pembangunan sejak dulu, melalui upaya rekonstruksi maupun dekonstruksi berbagai aturan formal yuridis yang berlaku megah saat ini. Uniknya, beberapa studi tentang masalah tanah adat di Papua hingga kini hanya bergerak pada tataran filosofis dan sangat simplikatif dalam memaknai konflik tanah. Studi-studi itu umumnya hanya memposisikan Orang Papua seakan-akan terlepas dari gerbong kepentingan ekonomi global, serta digambarkan sebagai suatu masyarakat yang romantis tanpa proses dinamika sehingga mati-matian perlu dijaga kelestariannya (Erari, 1999; Sirait dkk., 2009; Suparlan, 1994; Wanembu Zadrak dkk., 1997; Yapo, Pide, \& Nur, 2013). Celakanya upaya-upaya ini hanya sebatas membangun retorika dan belum diformat secara utuh agar mampu mengeleminir konflik tanah yang kini tengah melanda di berbagai kawasan Papua.

Riset ini secara prinsipil akan menutup berbagai kekurangan itu melalui model pendekatan sosio-kultural pertanahan yang selama ini dianggap klasik dan kurang diperhitungkan dalam proses perencanaan pembangunan, khususnya penatagunaan tanah. Pendekatan ini sangat berarti bagi perencana untuk Supiori kenali, memahami dan menjelaskan berbagai kondisi nyata kehidupan masyarakat yang terkait dengan kondisi land tenure and use system mereka untuk mencari penyelesaian konflik maupun keberlanjutan proses pembangunan. Aspek-aspek sosio-kultural pertanahan tersebut terkait dengan sejarah lokal, struktur sosial, institusi lokal dan pranata budaya serta berbagai mekanisme perubahannya. Sadar atau tidak muatan sosio-kultural pertanahan justru berdampak luas bila terjadi perubahan status penguasaan.

Tanah di Papua bukan tidak ada yang memiliki, karena suku-suku bangsa yang hidup di berbagai pelosok daerah ini menganggap tanah sekaligus hutan, meskipun belum terjamah manusia adalah hak mereka. Hak ini tidak terlepas dari interpretasi terhadap nilai sosio-kultural pertanahan, yakni; tanah sebagai nilai kultural, tanah sebagai bagian dari struktur sosial, tanah sebagai fenomena ekonomi dan tanah sebagai fenomena politik (Wenehen, 2003). Keempat dimensi sosial anatomi tanah tersebut, selalu bermain dalam penentuan sistem penguasaan dan pemanfaatan tanah (land tenure and land use system) berdasarkan struktur dan unit sosial terkecil, seperti keret dan marga. Hak ini 
diikat oleh adanya hubungan genealogis baik bersifat patrilineal maupun matrilineal terhadap territorial yang diklaim sebagai hak kolektif.

Kondisi sistem penguasaan dan pemanfaatan tanah semacam di atas akan mengalami persoalan bila terjadi perubahan status akibat masuknya kepentingan luar. Pelepasan tanah komunal dalam konteks masyarakat adat, sebenarnya tidak mengenal adanya pemindahan hak (hanya hak pakai), karena hal ini masih terkait dengan konsepsi filosofi tanah sebagai "ibu atau mama" (Erari, 1999; Wenehen, 2003). Namun jika suatu saat sebidang tanah ingin dilepas, harus dilakukan "musyawarah" antar semua unit sosial melalui institusi dan pemimpin lokal setempat untuk berdiskusi dan memecahkan bersama bagaimana jalan keluar terbaiknya. Keberadaan institusi dan pemimpin lokal sangat strategis dalam memayungi kepentingan masyarakat menurut pranata sosial budaya yang berlaku secara lisan di daerah kekuasaannya (Wenehen, 2010). Secara simultan semua pranata tersebut akan mengalami perubahan akibat perkembangan masyarakat maupun desakan dari luar (pembangunan). Salah satu perubahan yang sangat mendasar di Papua saat ini adalah terkait dengan masuknya perekonomian "uang" yang mulai merembes ke daerah pedesaan bahkan pedalaman. Akibatnya hubungan sosial maupun pola pemilikan dan pengelolaan tanah hanya terpusat pada beberapa orang sebagai property. Tetapi juga masalah tuntutan ganti rugi kepemilikan hak ulayat tanah adat di berbagai kabupaten dan kota di Papua seringkali menjadi penyebab terhambat kegiatan investasi di daerah tersebut (Muhsidin, 2014). Perubahan semacam ini kemudian akan memunculkan hak domain atas tanah lebih bersifat mercantile domain, dimana tanah diperlakukan sebagai barang dagangan (Wolf, 1966). Padahal dalam konteks lokal, tidak dikenal adanya jual-beli dan hak perorangan atas tanah, melainkan hanya ada hak kolektif (bersama) dalam kelompok suku, keret dan marga seperti yang telah didiskusikan di atas.

Terjadinya perubahan pandangan atas tanah tersebut, sebenarnya sangat terkait dengan kondisi umum Papua saat ini yang diperhadapkan pada tiga perubahan mendasar, yakni; pemberian otonomi khusus (OTSUS), pemekaran wilayah dan lahirnya civil society, seperti pendapat Antonio Gramsci dalam menganalisis hegemoni perubahan masyarakat pada suatu negara ditengarai oleh tiga kekuatan, yakni; economic, state dan civil society. Hegemoni perubahan ini merupakan reaksi atas tuntutan Orang Papua untuk diakui dan dihormati hak-hak dasar mereka, termasuk tanah adatnya yang selalu menjadi sumber konflik. Karena itu sebelum kondisi ini lebih parah, diperlukan proses dan tahap perencanaan pembangunan agar justru tidak menimbulkan disintegrasi antara kepentingan masyarakat adat dan berbagai introduksi perubahan dari luar di kawasan perbatasan Papua yang unik dan tidak jarang terjadi gejolak keamanan. Harapannya adalah agar lewat riset ini akan memberi justifikasi bahwa pendekatan keamanan tradisional yang bertumpu pada aspek kemiliteran saja tidaklah cukup. Namun harus juga mengakomodasi pendekatan keamanan non-tradisional dengan perspektif human security dalam bentuk jaminan terhadap economic security dan food security mutlak diperlukan (Setiawan, 2010). Berdasarkan hal tersebut tersebut, artikel ini akan menjelaskan tentang bagaimana pola penguasaan dan pemanfaatan tanah adat penduduk setempat, yakni orang Supiori menurut sejarah lokal, struktur sosial, institusi lokal dan pranata budaya. 


\section{Metode}

Penelitian ini merupakan penelitian deskriptif kualitatif dengan pendekatan etnografi. Lokasi penelitian di Kampung Sorendiweri Distrik Supiori Timur Kabupaten Supiori, Provinsi Papua. Dengan subjek penelitian yaitu orang Supiori. Kampung ini terletak di pusat ibu kota Kabupaten Supiori di Sorindeweri. Jenis data dan teknik pengumpulan data dalam penelitian teridiri dari data Primer dan sekunder. Data primer terdiri atas; (1) Keadaan umum lokasi kampung meliputi; tata letak dan geografis, pemerintahan dan batas administrasi kampung, topografi, demografi, infrastruktur sarana prasarana kampung, penjangkauan dan transportasi; (2) Aspek penguasaan dan pemanfaatan tanah adat, meliputi; sejarah lokal, struktur sosial, institusi lokal, konflik tanah adat dan pranata sosial budaya penduduk setempat. Sedangkan data Sekunder yang dibutuhkan sesuai dengan fokus studi ini, nyaris hampir tidak ada, maka data-data yang bisa diakses hanya melalui data-data spasial (peta-peta) lokasi studi dan monografi kampung.

Kemudian, teknik pengumpulan data pada studi ini pertama-tama dilakukan delineasi dan identifikasi letak lokasi permukiman melalui peta dan data-data sekunder yang telah diperoleh. Berdasarkan informasi data awal tersebut, dilakukan penyusunan instrumen baik terkait dengan pedoman pertanyaan untuk menjangkau berbagai data yang dibutuhkan dalam studi. Kegiatan pegumpulan data dan informasi yang dibutuhkan dijangkau dengan teknik-teknik sebagai berikut; (1). Kegiatan wawancara dengan menggunakan pedoman pertanyaan terhadap tokoh-tokoh adat terkait dengan pola pengusaaan dan pemanfaatan tanah dan konflik yang terjadi beserta resolusinya pada penduduk di Kampung Yengarbun dengan teknik snow ball sampling. (2). Kegiatan Focus Group Discusion (FGD) untukpengumpulan data yang terkait dengan aspirasi dan apresiasi masyarakat setempat. Kegiatan diskusi ini melibatkan seluruh lapisan sosial masyarakat di kampong lokasi studi maupun stakeholders.

Setelah data sekunder dan data primer dikumpulkan, selanjutnya dilakukan kompilasi dan dipilah-pilahkan menurut ruang lingkup, maksud, tujuan dan keluaran studi ini. Uraian metode analisis data yang digunakan dalam studi ini sangat menentukan potensi budaya penduduk dalam mendukung program pariwista di Kampung Sorendiweri. Dengan demikian tahapan untuk analisis kondisi faktual budaya pada studi ini akan berdasarkan pada data primer yang diperoleh dari hasil wawancara dan FGD. Hasil kompilasi data ini nantinya menunjukkan bagaiamana pola penguasaan tanah dan pemanfaataanya berdasakan perspektif emik dari penduduk lokal di kampung Sorendiweri.

\section{Hasil dan pembahasan}

\section{- Penguasaan, pemanfaatan, dan konflik tanah}

Secara konseptual, permasalahan pertanahan/agraria terdiri atas dua aspek utama yang berbeda, yaitu aspek penggunaan dan pemanfaatan tanah serta aspek penguasaan dan pemilikan tanah. Hal ini tampak secara tegas dalam Ketetapan Majelis Permusyawaratan Rakyat Nomor IX Tahun 2001, tentang Reforma Agraria, dimana dalam Pasal 2 yang menyatakan bahwa: "Pembaruan agraria mencakup suatu proses yang berkesinambungan berkenaan dengan penataan kembali penguasaan, pemilikan, 
penggunaan, dan pemanfaatan sumber daya agraria". Aspek penguasaan dan pemilikan tanah berkaitan dengan bagaimana relasi hukum antara manusia dengan tanah yang lebih berdimensi "stabilitas", sedangkan aspek penggunaan dan pemanfaatan berkenaan dengan bagaimana tanah digunakan untuk meningkatkan kesejahteraan yang lebih berdimensi "pertumbuhan".

Diketahui setiap negara mempunyai aturan tentang hak-hak penguasaan dan pemilikan tanah berdasarkan konsep dan teori hukum tertentu yang dimodifikasi sesuai dengan situasi dan kondisi yang dihadapi dan kebutuhan yang harus dipenuhi. Pada hakekatnya pengaturan hukum tentang hak-hak penguasaan atas tanah itu berisikan serangkaian wewenang, kewajiban dan atau larangan bagi pemegang haknya untuk berbuat sesuatu dengan tanah yang sudah dihakinya. Di Indonesia, dalam prakteknya dan masih terjadi sampai saat ini dalam persepsi masyarakat, bahwa ada berbagai sumber hukum tentang penguasaan tanah ini, yaitu ada yang bersumber dari hukum adat, atau hukum barat, dan atau hukum nasional. Semua persepsi ini dapat terjadi karena belum seluruh tanah di persada Negara Kesatuan Republik Indonesia ini dilakukan Pendaftaran Tanah yang legalistik berdasarkan hukum tanah nasional (UUPA No. 5 Tahun 1960). Dengan demikian, dalam mengkaji kondisi suatu wilayah dari aspek pertanahan, bahwa selain memperhatikan aspek penggunaan tanah yang terbangun di atasnya, maka perlu juga diperhatikan aspek penguasaan tanah yang melekat dan ada di wilayah tersebut. Pada dasarnya penguasaan tanah merupakan faktor kunci dalam perencanaan wilayah. Artinya, semakin baik data dan informasi tentang penguasaan tanah, maka akan semakin mempermudah proses perencanaan di suatu wilayah.

Diketahui bersama bahwa hubungan manusia dengan tanah merupakan hubungan timbal balik dan abadi yang seharusnya bersifat mesra. Hubungan mesra ini akan terjalin saat sekarang dan yang akan datang bila kebijaksanaan penggunaan tanah saat kemarin sesuai dengan kualitas tanahnya. Oleh karena itu, aspek informasi penggunaan tanah ini perlu dipertimbangkan sebagai prioritas utama dalam sistem informasi spasial kegiatan pembangunan, termasuk kegiatan penyusunan ketersediaan tanah. Penggunaan tanah adalah wujud tutupan permukaan bumi baik yang merupakan bentukan alami maupun buatan manusia. Secara ringkas dapat dinyatakan bahwa penyusunan peta penggunaan tanah, salah satunya bertujuan menggambarkan informasi jenis aktivitas sosial-ekonomi-budaya masyarakat di suatu wilayah, sehingga apabila kita mengkaji peta penggunaan tanah dari suatu wilayah, maka kita dapat menduga intensitas aktivitas utama masyarakat yang berkembang di wilayah tersebut. Artinya, pola penggunaan tanah di atas muka bumi mencerminkan tingkat dan orientasi kehidupan masyarakat di wilayah tersebut. Selain itu, diketahui pula bahwa pola penggunaan tanah pada hakekatnya merupakan hasil perpaduan antara faktor sejarah, faktor fisik, serta faktor sosial, budaya, dan ekonomi. Dinamika aktivitas masyarakat dapat dikaji dari perubahan pola penggunaan tanah yang terjadi.

Kemudian, Konflik dalam riset ini dimaknai sebagai sebuah proses sosial, dimana setiap unit sosial baik keret dan marga dalam suku bangsa Supiori memiliki sejarah lokal penguasaan dan pengelolaan tanah adat yang saling berbeda-beda dan tidak jelas, menyebabkan timbul konflik internal antar mereka baik sifatnya tertutup maupun 
terbuka. Pemikiran ini sejalan dengan pandangan Soemardjono bahwa pemahaman yang utuh terhadap keberadaan hak ulayat mengisyaratkan pemahaman tentang struktur kemasyarakatan, sehingga dapat dihindari kesalahan untuk berurusan dengan pihak yang tidak berkompeten memutuskan (Soemardjono, 2001). Lebih lanjut Geertz, menegaskan bahwa struktur kepemilikan tanah merupakan bentuk yang spesifik dari pola sosial dan hanya menampakan diri dalam ukiran-ukiran kelembagaan yang rumit (Geertz, 1983).

Duane Ruth-Hafellbower berpendapat bahwa konflik adalah kondisi yang terjadi ketika dua pihak atau lebih menganggap ada perbedaan posisi yang tidak selaras, tidak cukup sumber dan tindakan salah satu pihak menghalangi, atau mencampuri atau dalam beberapa hal membuat tujuan pihak lain kurang berhasil (Ruth-Haffelbower, 1998). Konflik tidak bisa dihindari oleh setiap aktor, namun yang paling penting adalah cara untuk menyelesaikan konflik agar ancaman (threat) bisa menjadi kesempatan (oppurtunity) dan bahaya yang ditimbulkannya konflik terbuka secara meluas bisa dilokalisasi dengan membangun suatu model pencegahan dan penanggulangan dini (Sihbudi \& Nurhasim, 2001). Menurut Miall, dkk mengutarakan bahwa pihak-pihak yang berkonflik biasanya cenderung melihat kepentingan mereka sebagai kepentingan yang bertentangan secara diametrikal (Miall, Rambotham, \& Woodhouse, 2000). Berdasarkan buku pengelolaan konflik dari The British Council bahwa penyelesaian konflik yang terjadi dapat dilakukkan dengan tiga cara, yaitu; (1) Negosiasi, suatu proses untuk memungkinkan pihak-pihak yang berkonflik untuk mendiskusikan berbagai kemungkinan pilihan dan mencapai penyelesaian melalui interaksi tatap muka. (2) Mediasi, suatu proses interaksi yang dibantu oleh pihak ketiga sehingga pihak-pihak yang berkonflik Supioriukan penyelesaiaan yang mereka sepakati sendiri; (3) Arbitrasi atau perwalian dalam sengketa, tindakan oleh pihak ketiga yang diberi wewenang untuk memutuskan dan menjalankan suatu penyelesaian (Fisher Simon dkk., 2001).

Secara tradisional, tugas penyelesaian konflik adalah membantu pihak-pihak yang merasakan setuasi yang mereka alami sebagai sebuah setuasi zero-sum (keuntungan diri sendiri adalah kerugian pihak lain). Agar melihat konflik sebagai keadaan non zero-sum dimana kedua belah pihak dapat memperoleh hasil atau keduanya sama-sama tidak memperoleh hasil dan kemudian membantu pihak-pihak yang berkonflik berpindah ke arah hasil yang positif (Miall et al., 2000). Ada tiga pandangan mengenai konflik, yaitu: (1) Pandangan Tradisional, menyatakan bahwa konflik harus dihindari karena akan menimbulkan kerugian. Dalam aliran ini memandang konflik sebagai sesuatu yang tidak menguntungkan, sesuatu yang buruk dan selalu merugikan dalam organisasi. Oleh karenanya, konflik harus dicegah dan dihindari sebisa mungkin dengan mencari akar permasalahannya; (2) Pandangan Hubungan Kemanusiaan, menyatakan bahwa konflik merupakan sesuatu yang alamiah, wajar dan tidak terelakkan dalam setiap kelompok manusia. Konflik tidak selalu dipandang buruk karena memiliki potensi kekuatan yang positif di dalam menentukan kinerja kelompok. Konflik ini tidak selamanya bersifat merugikan, bahkan bisa menguntungkan, yang oleh karena itu konflik harus dikelola dengan baik; (3) Pandangan Interaksionis, menyatakan bahwa konflik bukan sekedar sesuatu kekuatan positif dalam suatu kelompok, akan tetapi 
mutlak diperlukan untuk suatu kelompok agar dapat berkinerja positif, dengan demikian konflik harus diciptakan. Pandangan ini didasarkan pada keyakinan bahwa organisasi yang harmonis, tenang dan damai ini justru akan membuat organisasi itu menjadi statis dan tidak inovatif. Hal ini kemudian berdampak pada kinerja organisasi yang menjadi rendah.

Dari berbagai diskusi di atas, maka dapat disumpulkan bahwa konflik muncul karena terjadinya perbedaan kepentingan dan tidak selamanya konflik dipandang sebagai sesuatu yang berdampak negatif, namun secara positif dapat membantu pihak-pihak yang berkonflik ke arah yang lebih baik. Karena tujuan pokok riset ini adalah mencari model penyelesaian konflik tanah adat dan pemberdayaan masyarakat yang berbasis pada institusi lokal yang khas di kawasan perbatasan Papua. Karena umumnya berbagai hasil riset hasil riset yang telah dilakukan, telah mengungkapkan bahwa konflik tanah antara masyarakat adat sendiri secara internal maupun antara masyarakat adat dan pihak luar (pemerintah dan swasta) selama ini ditengerai oleh sejumlah masalah ketidakjelasan klaim kepemilikan, ganti rugi dan mekanisme penyelesaian. Hasil riset Sirait, dkk pada Orang Moni di Distrik Sugapa-Papua memperlihatkan bahwa karena status kepemilikan tanah adat banyak belum terdokumentasi dan tidak ada bukti-bukti tertulis, membuat informasi tentang tanah adat kerap kali kabur atau bahkan simpang siur (Sirait dkk., 2009). Ketiadaan ini, pada gilirannya menjadi kendala bagi setiap aktivitas berhubungan dengan tanah adat yang menjurus kepada sengketa vertikal maupun horizontal. Kemudian hasil riset Yapo, dkk pada empat lokasi penyebaran transmigrasi di Kabupaten Merauke menunjukkan bahwa tanah adat dijual oleh pemilik tanah maupun juga oleh orang lain yang dibuktikan dengan dokumen berita acara penyerahan tanah dan bentuk ganti kerugiannya (Yapo et al., 2013). Namun setelah puluhan tahun berlalu dengan melihat perkembangan yang terjadi di Wilayah Transmigrasi, masyarakat adat tidak mempunyai akses lagi atas tanah yang bukan milik mereka.

Masyarakat adat berharap adanya ganti kerugian yang layak, tetapi Departemen Transmigrasi mengatakan bahwa masalah ganti kerugian atas tanah transmigrasi sudah final. Isu dan konflik yang berhubungan dengan keberadaan pengelolaan serta pemanfaatan tanah ulayat masyarakat hukum adat masih tetap mengemuka di berbagai daerah ${ }^{1}$. Isu-isu konflik tersebut baik akibat tumpang tindih tapal batas hak penguasaan, sejarah silsilah keluarga, dan pemetaan (mapping) hak ulayat, tetapi juga berbagai upaya melalui musyawarah lewat aparat kampung/desa, pemimpin adat, penguatan lembaga adat, penerbitan sertifikat, penyusunan peraturan daerah dan pemberlakuan hukum melalui pemberian sanksi perdata maupun pidana selama ini, ternyata belum efektif untuk mengeleminir konflik tanah yang terjadi (Amahorseya, 2008; Dorthia, 2012;

\footnotetext{
1 Lihat Data Konsorsium Pembaruan Agraria (KPA) sepanjang 2004 -2014, terjadi 1.391 konflik agraria di seluruh Indonesia, dengan areal konflik seluas 5.711 .396 hektar dengan lebih 926.700 keluarga harus menghadapi ketidakadilan dan konflik berkepanjangan.Masalah sektoralisme kebijakan dan kelembagaan dalam pengelolaan sumber-sumber agraria menjadi penyumbang konflik. Berdasarkan sektor, konflik agraria sektor perkebunan 536 kasus, infrastruktur 515 kasus, kehutanan 140 kasus, tambang 90 kasus, pertanian 23 kasus, pesisir-kelautan enam kasus dan lain-lain.Intimidasi dan kriminalisasi dialami warga. Cara-cara represif aparat kepolisian dan militer dalam penanganan konflik agraria masih terjadi dan mengakibatkan 1.354 orang ditahan, 553 luka-luka, 110 tertembak peluru aparat dan 70 tewas. Masyarakat Adat Vs Perusahaan Sawit Dominasi Konflik SDA di Kalsel. Sapariah Saturi. http://www.mongabay.co.id November 14,2014
} 
Katmo, 2015; Lah, 2014; Vidawati, 2009; Windari, 2010, 2014). Filosofi mendasar mengenai tanah sebagai hak ulayat bagi orang Papua adalah berhubungan erat dengan kekerabatan, kekuasaan, kepemimpinan, sumber nafkah, ritus dan alam roh. Inilah yang disebut dengan hubungan hak ulayat yang bersifat "religio magis". Artinya, sebagai suatu bagian integral dari kepribadian dan ikatan batin yang sangat kuat terhadap tanah. Karena itu, ketika berbicara tentang "sistem penguasaan tanah"e yang dimaksud adalah pemilik dan pewaris tanah atau dengan kata lain mereka yang mempunyai hak atas tanah di wilayah tertentu (Deda \& Mofu, 2014).

\section{- Pemaknaan tanah adat di kampung Sorendiweri}

Secara administrasi Kampung Sorendiweri terbentuk difinitif pada tahun 1986 dengan memiliki luas $0,023 \mathrm{~km}^{2}$. Tata letak Kampung Sorendiweri sebagai berikut; pada sisi Selatan berbatasan dengan Laut, sisi Utara berbatasan dengan Kampung Korido, sisi Timur berbatasan dengan Kampung Paryem dan sisi Barat berbatasan dengan Kampung Mansoben. Letak Kampung Sorendiweri berada di pusat ibu kota Kabupaten Supiori dan ibu kota Distrik Supiori Timur, maka kondisi kampung ini tidak lagi terlihat penataan kampung yang asli, namun sudah berkembang pesat dengan berbagai pusat pelayanan publik seperti pasar, toko, terminal, bank, dan kantor pemerintahan.

Pemaknaan tanah dalam konteks masyarakat di Supiori, khususnya di beberapa kampung seperti Sorindeweri, Paryem dan Wafor seperti pada umumnya pada masyarakat Papua bahwa tiap masyarakat memiliki pandangan/persepsi berbeda-beda terhadap tanah, sebagai tempat melangsungkan hidup dan mencari nafkah. Karena itu pada kawasan tanah yang meskipun terlihat kosong atau belum dijamah oleh aktivitas manusia dan tidak bernilai ekonomis, namun dalam kondisi ideal pandangan masyarakat terhadap kawasan tersebut bukanlah tanpa pemilik atau penguasa. Dengan begitu, mereka mempunyai kewajiban untuk melindungi dan mempertahankan tanah sebagai hak mereka, jika ada intervensi dari luar untuk mencoba mengganggu atau mengalihkan.

Orang Supiori percaya bahwa tanah yang kini menjadi hak adat mereka dijaga oleh Mananwir. Tokoh ini secara tradisional dianggap sebagai pusat segala kepercayaan mereka yang bukan saja berkaitan dengan tanah, tetapi juga berhubungan dengan segala potensi sumber daya alam yang ada baik di dalam tanah maupun di atas tanah, seperti; telaga, sungai, hutan, pohon, batu-batuan, pasir dll. Namun yang lebih penting dalam konsepsi mereka adalah keberadaan tokoh ini sebagai pengatur kehidupan manusia dan kosmos/alam sekitarnya.

Berdasarkan interpretasi terhadap "tanah" di atas, kemudian sangat mempengaruhi dua persepsi yang sangat mempengaruhi orang Supiori dalam penguasaan dan pemanfaatan tanah yang kini sebagai hak ulayat mereka; Pertama, adanya pandangan Historiosuksesif yaitu tanah dianggap sebagai simbol kejayaan leluhur dimasa silam, sehingga jangan ada orang masuk mengganggu, meskipun dengan cara membeli dengan harga yang layak. Pandangan semacam ini sebenarnya terkait dengan kondisi hak ulayat tanah dan hutan adat yang saat dikuasai orang Supiori merupakan lokasilokasi dipertahankan dan diperjuangkan melalui perang antar suku, melalui kegiatan pengauaan dan mencari budak, seperti dikisahkan dalam Upacara Adat Fan Nanggi. 
Kedua, adanya pandangan Psikomonumentif yaitu tanah dianggap sebagai harga diri, warisan dan monumen keluarga, sehingga jangan ada orang lain mengganggu. Pandangan ini mencerminkan adanya semacam ikatan psikologi yang kuat terhadap lokasi-lokasi yang dianggap sebagai tempat bersejarah pada saat mereka melakukan migrasi/mobilitas atau asal-usul moyang mereka pertama tinggal, kemudian menyebar dan kini secara permanen keturunannya lokasi perkampungan yang ada.

Dari kedua padangan baik Historiosuksesif dan Psikomonumentif di atas, memperlihatkan bahwa terjadinya penolakan terhadap berbagai upaya untuk mengkonversi tanah/hutan adat dari berbagai pihak luar untuk kepentingan pembangunan bidang perkebunan saat ini di wilayah ulayat adat mereka, selalu mendapat reaksi yang cukup keras dari mereka. Hal ini sebenarnya terkait dengan tuntutan dan pengalihan hak pengelolaan dai pihak luar tersebut. Misalnya, kasus pelepasan tanah untuk pembangunan kawasan wisata Pantai Wisata Wafor yang kini telah dibangun cottage dan pondok. Ketika adanya pemberian ijin lokasi antara masyarakat dan pemerintah daerah tahun 2015 untuk menggunakan lahan tersebut, maka mulai saat itu terjadi sengketa antara masyarakat dengan masyarakat seperti Klen Sauyas dan Klen Imbab, maupun secara vertikal dengan pemerintah. Di lain pihak, terjadinya sengketa semacam ini bila dipahami sebenaranya masyarakat sangat mengapresiasi upaya pemerintah memanfaatkan kawasan tersebut kepentingan pembangunan pariwisata. Namun demikian, begitu dominanya kedua pandangan penduduk dalam menginterpretasi tanah/hutan adat mereka seperti di atas, maka proses perubahan dan pengalihan status penguasaan dan pengelolaan tersebut juga harus mengikuti tata cara yang mereka bisa pahami dengan baik. Karena pandangan mereka terhadap tanahadat yang selama ini, seakan-akan dipaksa oleh pihak luar untuk kepentingan ekonomi semata, padahal dalam konteks lokal filosofi dan fungsi tanah tersebut belum berubah ke pandangan yang sifatnya Eko-materialistik yaitu tanah dianggap sebagai bagian dari ekosistem yang bersifat "non-privat" sehingga tanah dihargai secara materialistik atau uang. Hal ini berarti fungsi sosial tanah (historiosuksesif dan psikomonumentif) akan berubah dalam konteks yang lebih kompleks atau pola pemilikan tanah yang bersifat komunal akan berubah menjadi kepemilikan individu yang diperkuat dengan legalitas formal atau sertifikasi.

\section{- Pranata kepemilikan tanah adat}

Institusi atau pranata sosial budaya dalam konteks ilmu sosial memiliki pengertian atau makna sangat berbeda dengan disiplin ilmu lainnya. Pengertian tersebut mengacu pada aturan atau norma-norma khusus yang ditemui dalam masyarakat. Keterkaitan antar pranata dalam konteks pemahaman terhadap suatu masyarakat dinilai sangat perlu, karena itu aspek-aspek yang dikaji dalam sosio-kultural pertanahan yang disoroti adalah pranata-pranata sosial budaya yang berhubungan dengan berbagai kehidupan, dimana akan diguanak dan sebagai acuan utama dalam penanganan dan pemberdayaan pemilik pranata-pranata tersebut. Keberadaan pranata-pranata yang dideskripsikan berikut yang berhubungan pola dan sistim penguasaan tanah adat pada Orang Supiori akan memperlihatkan bagaimana proses analitical and ratonal penduduk dalam menginterpretasikan tentang tanah/hutan adat yang dimilikinya. 
Pola penguasaan tanah pada Orang Supiori bersifat komunal. Sifat komunalitas penguasaan tanah semacam ini dapat diuraikan menurut lokasi perekampungan yang kini dihuni oleh masing-masing kelompok unit sosial klen, sebagai berikut. Misalnya kawasan tanah adat di Kampung Wafor diklaim oleh Klen Sauyas dan Imbab yang ada di kampong ini sebagai hak mereka. Namun dalam kedua klen tersebut telah ada batasbatas alam yang sangat jelas, kemudian di dalamnya ada juga kelompok unit social klen yang yang terfragmentasi dalam kelompok klen. Pada kelompok sosial marga tersebut tanah yang menjadi warisan leluhur atau orang tua mereka terbagi lagi berdasarkan status kedudukan anak tertua atau keturunan tertua, keturunan tengah dan keturunan terakhir. Di dalam lingkaran marga inilah setiap pemiliknya melakukan aktivitas mata pencaharian hidup. Dengan demikian kelompok unit social klen pada Orang Supiori di Wafor seperti; Kmur, Makis, Manampaisen, Pombos dan Imbir. Walaupun tanah di dalam kampung Wafor sendiri sudah dibagi menurut klen-klen tersebut, namun setiap klen bebas mencari makan di tanah milik klen lain. Prinsip dasar yang diberlakukan oleh Orang Supiori dimana semua klen yang berada di dalamnya memiliki persamaan prinsip bahwa mereka secara komunal bersama-sama mencari nafkah atau menjalankan kegiatan ekonomi tradisional. Tiap klen memiliki tanah dengan batas yang jelas dan tegas dengan klen lain. Tanah milik klen tidak lagi dibagi lagi kepada kepala-kepala rumah tangga sebagai hak utama. Sebaliknya, justru kumpulan dari keluarga-keluarga yang se-klen itulah yang memegang hak milik atas tanah klen. Misalnya, keluargakeluarga klen Sauyas sama-sama memiliki semua tanah yang telah dklaim sebagai miliknya Pien.

Dari sejarah penguasaan dan pengelolaan tanah adat di kawasan Supiori, terutama beberapa kampung yang menjadi lokasi studi seperti Kampung Sorendiweri, Paryem dan Wafor, mereka memiliki pembagian yang jelas antara marga yang berstatus sebagai asli dan sebagai pendatang. Dari hasil diskusi kelompok di Kampung Wafor, identifikasi marga asli dan pendatang tersebut, Marga asli di Kampung Wafor adalah Sauyas, Imbab dan Swom, sedangkan marga pendatang adalah Kmur, Makis, Manampaisen, Pombos dan Imbir.

\section{Kesimpulan}

Pola penguasaan tanah pada penduduk setempat bersifat komunal di tingkat marga, dimana kedudukan Mananwir sangat sentral dan mengatur dan menata hak-hak atas tanah. Pada penelitian ini ditemukan bahwa pandangan psikomonumentif dan historiosuksesif atas tanah adat sangat dominan, karena itu klaim penguasan atas tanah adat di kalangan marga seperti Sauyas lebih berdasarkan atas sejarah dan hubungan antara marga dengan kondisi alam sekitarnya yang merupakan peninggalan moyang terdahulu. Konflik atas tanah adat baik secara vertikal maupun horizontal kini tengah terjadi di kalangan penduduk, hal ini merupakan dampak langsung setelah dibukanya wilayah ini sebagai sebuah kabupaten baru yang tentunya berhubungan dengan percepatan pembangunan yang umumnya membutuhkan tanah.

Konflik atas tanah adat baik secara vertikal maupun horizontal kini tengah terjadi di kalangan penduduk, hal ini merupakan dampak langsung setelah dibukanya wilayah ini sebagai sebuah kabupaten baru yang tentunya berhubungan dengan percepatan pembangunan yang umumnya membutuhkan tanah. Pemerintah daerah perlu segera 
memfasilitasi dan memediasi konflik antara marga dan pihak luar yang kini tengah bersengketa akibat hak penguasaan tanah di antara mereka yang semakin kabur.

\section{Referensi}

Amahorseya, R. (2008). Penyelesaian Sengketa Tanah Hak Ulayat Di Kabupaten Nabire Provinsi Papua (Studi Kasus Sengketa Tanah Bandara Udara Nabire). Universitas DIponegoro.

Anwar, M. Z. (2015). Institusi Lokal untuk Kesejahteraan Bersama. Yogjakarta: Policy Brief Institute for Research and Empowerment (IRE).

Bahriadi \& Lucas. (2002). Merampas Tanah Rakyat; Kasus Tapos dan Cimacam. Jakarta: KPG (Kepustakaan Populer Gramedia).

Coleman, J. S. (1990). Foundations of Social Theory. Cambridge: Harvard University Press.

Deda, A., \& Mofu, S. (2014). Masyarakat Hukum Adat Dan Hak Ulayat Di Provinsi Papua Barat Sebagai Orang Asli Papua Ditinjau Dari Sisi Adat Dan Budaya: Sebuah Kajian Etnografi Kekinian. Jurnal Administrasi Publik Unpar, 11(2), 11-22.

Dorthia, A. A. F. (2012). Perlindungan Hukum Terhadap Pemegang Hak Atas Tanah Adat Yang Dikuasai Tanpa Hak Oleh Pihak Lain Dihubungkan Dengan Pasal 2 Undang-Undang Nomor 5 Tahun 1960 Tentang Undang-Undang Pokok Agraria. Universitas Pasundan.

Eliza. (2011). Strategi Penguatan Institusi Lokal; Optimalisasi Forum Warga sebagai Media Pendidikan Politik Masyarakat Desa di Desa Sumber Agung Moyudan Kabupaten Sleman, DIY. UGM-Yogjakarta.

Erari, K. P. (1999). Tanah Kita, Hidup Kita; Hubungan Manusia dengan Tanah di Irian Jaya sebagai Persoalan Teologis. Jakarta: Pustaka Sinar Harapan.

Esman, Milton, J., \& Uphoff, N. T. (1984). Local Organization, intermediaries rural development. London: Cornell Unversity Press.

Fisher Simon dkk. (2001). Mengelola Konflik: Ketrampilan \& Strategi Untuk Bertindak. (Jakarta). The British Council.

Fukuyama, F. (1995). Trust Kebijakan Sosial dan Penciptaan Kemakmuran. Yogyakarta: Qalam.

Geertz, C. (1983). Agriculture Involution; The Processes of Ecological Change in Indonesia. Barkeley: University of California Press.

Husen, A. S. (2002). Konflik Pertanahan; Dimensi Keadilan dan Kepentingan Ekonomi. Jakarta: Sinar Harapan.

Imhar, D. E., Sumartono, \& Suwondo. (2009). Pemberdayaan institusi lokal dan implikasinya bagi masyarakat (Studi Implementasi Kebijakan Peningkatan Kualitas Sumberdaya Manusia Melalui Pendidikan Dan Pelatihan Di Desa Kundur, Kundur, Kabupaten Karimun). 10(1), 78-97.

Imron, M. A., Soeprapto, H. R. R., \& Suwondo. (2002). Peran Institusi Lokal dalam Pembangunan Desa (Suatu Kajian Tentang Peran Lembaga Tahlil dalam Pembangunan Desa di Desa Simorejo Kecamatan Kanor Kabupaten Bojonegero). Univeristas Brawijaya Malang.

Katmo, H. (2015, Juni 26). Tanah dan Reforma Agraria di Papua. Kompasiana.

Lah, J. (2014). Peranan Kepala Adat dalam Penyelesaian Sengketa Tanah Ulayat di Kecamatan Sungai Boh Kabupaten Malinau. 2(4), 3273-3287.

Miall, H., Rambotham, O., \& Woodhouse, T. (2000). Resolusi damai konflik kontemporer: menyelesaikan, mencegah, mengelola dan mengubah konflik bersumber politik, sosial agama dan ras. Jakarta: Raja Grafindo Persada.

Muhsidin. (2014, November 18). Tuntutan Hak Ulayat Tanah Adat Hambat Investasi di Papua. https://papua.antaranews.com/.

Ngo, M. (1992). Hak Ulayat Masyarakat Setempat; Pelajaran dari Orang Kayan dan Limbai. Jakarta: PT. Pustaka LP3ES Indonesia. 
Partha, D., \& Ismail, S. (1999). Social Capital A Multifaceted Perspective. Washington DC: The World Bank.

Patriadi, H. B. (2010). Isu Perbatasan; Memudarnya "Imagined State"?. In Ludiro madu dkk. (Ed.), Mengelola Perbatasan Indonesia Di Dunia Tanpa Batas; Isu, Permasalahan dan Oilihan Kebijakan. Yogyakarta: Graha Ilmu.

Putnam, R. (1995). Social Capital. Pricenton: Pricenton University.

Rahmat, P. S. (2008). Memupuk Institusi Lokal dan Modal Sosial dalam Kehidupan Bermasyarakat. Diambil 5 Desember 2019, dari https://akhmadsudrajat.wordpress.com website: https://akhmadsudrajat.wordpress.com/2008/03/29/memupuk-institusi-lokaldan-modal-sosial-dalam-kehidupan-bermasyarakat/

Rahmawati, E. N. (2006). Peran Institusi Lokal dalam Pengembangan Ekonomi Wilayah (Studi Kasus: Proses Difusi Inovasi Produksi Pada Industri Gerabah Kasongan Bantul, DIY). Universitas Diponegoro Semarang.

Ruth-Haffelbower, D. (1998). Conflict and Peacemaking Across Cultures; Training for Trainers. Center for Peacemaking and Conflict Studies. CA: Fresno Pacific University.

Ruwiastuti, M. R. (1997). Penghancuran Hak Masyarakat Adat atas Tanah; Sistem Penguasaan Negara, Sengketa dan Politik Hukum Agraria. Bandung: KPA dan INFI-Pact.

Setiawan, A. A. (2010). Mengelola Perbatasan Indonesia-Papua New Guinea dengan Pendekatan Keamanan Non-Tradisional. In Ludiro Madu dkk. (Ed.), Mengelola Perbatasan Indonesia Di Dunia Tanpa Batas; Isu, Permasalahan dan Pilihan Kebijakan. Yogyakarta: Graha Ilmu.

Sihbudi, R., \& Nurhasim, M. (Ed.). (2001). Kerusuhan Sosial di Indonesia. Jakarta: Grasindo. Sirait dkk. (2009). Budaya dan Tanah Adat Orang Moni Di Distrik Sugapa, Papua. Jakarta: Pusat Kajian Pembangunan Masyarakat, Universitas Katolik Indonesia Atma Jaya.

Soemardjono, M. S. W. (2001). Kebijakan Pertanahan antara Regulasi dan Implementasi. Yogyakarta: LAPERA.

Suheri, A. (2015). Fakultas hukum universitas wiraraja sumenep - madura. Jurnal Jendela Hukum, 2(2), 33-43.

Suparlan, P. (1994). The Diversity of Culture in Irian Jaya. The Indonesia Quarterly, 22(2).

Vidawati, T. (2009). Peranan Kepala Adat Dalam Penyelesaian Sengketa Tanah (Studi Kasus Pada Suku Dayak Tobak Desa Tebang Benua Kecamatan Tayan Hilir Kabupaten Sanggau Kalimantan Barat). Universitas Diponegoro Semarang.

Wanembu Zadrak dkk. (1997). Masyarakat Adat Amungme di Wilayah Amungsa, Irian Jaya. In Maria Rita Ruwiastuti dkk. (Ed.), Penghancuran Hak Masyarakat Adat atasTanah. Bandung: KPA dan INFI-Pact.

Wenehen, A. (1999). Sosio-Kultural Pertanahan Di Kawasan Perbatasan Papua; Studi Pada Orang Walsa dan Fermanggem Di Kecamatan Waris-Jayapura. Jayapura.

Wenehen, A. (2003). PETSKHA VAI: Konflik Tanah Pada Orang Walsa Di Distrik Waris Kabupaten Keerom. Yogyakarta: Kunci Ilmu.

Wenehen, A. (2010). Orang Keerom Di Tengah Arus Perubahan; Eksistensi, Identitas Kultural dan Penguatan Kapasitas Lokal. Jurnal Antropologi Papua, 8(24).

Windari, R. (2010). Dilema Hukum Penyertifikatan Tanah Ayahan Desa di Bali(Studi Kasus Konflik Adat Tanah Ayahan Desa di Desa Adat Panglipuran). Jurnal IKA, $8(2), 205-219$.

Windari, R. (2014). Keberpihakan Regulasi Pertanahan Terhadap Hak Masyarakat Adat (Studi Kasus Sengketa Tanah Adat Di Desa Kubutambahan, Kecamatan Kubutambahan, Kabupaten Buleleng). Jurnal Ilmu Sosial dan Humaniora, 3(1), 328340. https:// doi.org/10.23887/jish-undiksha.v3i1.2923

Wolf, E. (1966). Peasant. New Jersey: Prentice-Hall.

Yapo, T. E., Pide, A. S. M., \& Nur, S. S. (2013). Ganti Kerugian atas Tanah Adat untuk Kepentingan Transmigrasi di Kabupaten Merauke. e-Journal Program Pascasarjana 
P-ISSN: 2527-9319; E-ISSN: 2548-9747

Unhas.

Yayasan Insan Sembada. (2016). Program Pengembangan Institusi Lokal. Karang Asem, Solo.

Zakaria, Y. (2000). Mensiasati Otonomi Daerah demi Pembaharuan Agraria. Bandung: KPA dan INFI-Pact. 